\title{
Acetylcholinesterase Gene Expression in Axotomized Rat Facial Motoneurons Is Differentially Regulated by Neurotrophins: Correlation with trkB and trkC mRNA Levels and Isoforms
}

\author{
Karl J.L. Fernandes, ${ }^{1,2}$ Nao R. Kobayashi, ${ }^{1,2}$ Bernard J. Jasmin, ${ }^{4}$ and Wolfram Tetzlaff ${ }^{1,2,3}$ \\ ${ }^{1}$ CORD (Collaboration on Repair Discoveries), and Departments of 2 Zoology and ${ }^{3}$ Surgery, University of British Columbia, \\ Vancouver, British Columbia, Canada V6T 1Z4, and ${ }^{4}$ Department of Cellular and Molecular Medicine, Faculty of Medicine, \\ University of Ottawa, Ottawa, Ontario, Canada K1H 8M5
}

\begin{abstract}
We examined the potential influences of muscle-derived neurotrophins on the acetylcholinesterase (AChE) gene expression of adult rat motoneurons. Seven days after facial nerve transection, both AChE mRNA and enzyme activity levels were markedly reduced in untreated and vehicle-treated facial motoneurons, suggesting positive regulation of motoneuron AChE expression by muscle-derived factors. Because skeletal muscle is a source of neurotrophin-3 (NT-3), NT-4/5, and BDNF, these neurotrophins were individually infused onto the proximal nerve stump for $7 \mathrm{~d}$, beginning at the time of axotomy. The trkB ligands NT-4/5 and BDNF prevented the downregulation of AChE mRNA and enzymatic activity, as determined by in situ hybridization, biochemical assay, and histochemical visualization of enzyme activity. In contrast, NT-3 had limited effects, and NGF was without effect. Because motoneurons normally express both trkB and trkC receptors and the trkC ligand NT-3 is the most abundant muscle-derived neurotrophin, we investi-
\end{abstract}

gated possible reasons for the limited effects of NT-3. In situ hybridization and reverse transcription-PCR both revealed a downregulation of trkC mRNA in axotomized motoneurons, which contrasted the upregulation of trkB expression. Furthermore, isoforms of trkC were detected carrying insertions within their kinase domains, known to limit certain trkC-mediated signal transduction pathways. Because the changes in trkB and trkC mRNA levels were not significantly altered by neurotrophin infusions, it is unlikely they were induced by loss of musclederived neurotrophins. These results demonstrate that NT-4/5 and BDNF stimulate AChE gene expression in motoneurons and support the concept that muscle-derived trkB ligands modulate the cholinergic phenotype of their innervating motoneurons.

Key words: acetylcholinesterase; axotomy; BDNF; motoneurons; NT-4/5; NT-3; neurotransmitter enzymes; retrograde signals
Neurotrophic factors (NTFs) derived from axonal targets profoundly influence neuronal survival, differentiation, and synaptic function in the developing and mature nervous system (Schotzinger et al., 1994; Munson et al., 1997; for reviews, see Landis, 1990; Lowrie and Vrbova, 1992; Davies, 1994; Thoenen, 1995; Greensmith and Vrbova, 1996). After axonal injury, which interrupts the bidirectional flow of neuron-target interactions, the majority of mature cholinergic neurons survive but rapidly decrease their expression of the cholinergic neurotransmitter synthesizing enzyme choline acetyltransferase (ChAT) (Lams et al., 1988; Peterson et al., 1990; Kou et al., 1995). Consistent with a model of target regulation of neurotransmitter enzymes, inf usion of pharmacological doses of putative target-derived NTFs restores ChAT immunoreactivity to axotomized cholinergic neurons (Hagg et al., 1989; Yan et al., 1994; Friedman et al., 1995).

\footnotetext{
Received July 23, 1998; accepted Sept. 16, 1998.

This work was supported by an operating grant from the Medical Research Council of Canada (W.T.) and studentships from the Rick Hansen Man in Motion Foundation (K.F.), the Natural Sciences and Engineering Research Council (K.F.), the Canadian NeuroScience Network (N.K. and K.F.), and the Government of Canada (N.K.). W.T. is the Rick Hansen Man in Motion Chair in Spinal Cord Research. Neurotrophins were kindly provided by Regeneron Pharmaceuticals Inc. (Tarrytown, NY). We thank Dr. Stanley Wiegand, Dr. John Steeves, and Dave Pataky for critical reading of this manuscript and valuable suggestions and Annie Bedard for expert technical assistance.

Correspondence should be addressed to Dr. Wolfram Tetzlaff, Department of Zoology, University of British Columbia, 6270 University Boulevard, Vancouver, British Columbia, Canada V6T 1 Z4.

Copyright (ㄷ) 1998 Society for Neuroscience $\quad 0270-6474 / 98 / 189936-12 \$ 05.00 / 0$
}

A second enzyme associated with cholinergic neurotransmission is acetylcholinesterase (AChE). Although AChE is found to be coexpressed with ChAT in mature cholinergic neurons, it is also expressed in the absence of ChAT in certain noncholinergic, noncholinoceptive regions of the adult nervous system (Levey et al., 1983; Greenfield, 1984; Landwehrmeyer et al., 1993; Legay et al., 1993; Hammond et al., 1994; Bernard et al., 1995). Furthermore, expression of AChE mRNA, but not ChAT, is an early event during neuronal differentiation (Coleman and Taylor, 1996). These observations may be accounted for by a variety of nonacetylcholine-related functions for AChE (Krejci et al., 1991; Layer et al., 1993; Dupree and Bigbee, 1994, 1996; Webb et al., 1996; Srivatsan and Peretz, 1997; for review, see Appleyard, 1992; Massoulie et al., 1993; Layer and Willbold, 1995). Thus, coregulation of ChAT and AChE cannot be assumed per se, because these enzymes may be differentially regulated after injury or in response to different NTFs.

Previously, we have shown that adult rat facial motoneurons undergo a reduction in AChE enzymatic activity after axotomy (Tetzlaff and Kreutzberg, 1984). Because mature motoneurons express trkB and trkC high-affinity tyrosine kinase receptors (Henderson et al., 1993), muscle-derived members of the neurotrophin family of NTFs may play a role in AChE regulation in motoneurons. Adult muscle produces the trkB ligands neurotrophin-4/5 (NT-4/5) (Timmusk et al., 1993; Funakoshi et al., 1993; Koliatsos et al., 1993) and possibly low levels of BDNF (Funakoshi et al., 1993; Griesbeck et al., 1995). Several studies have 


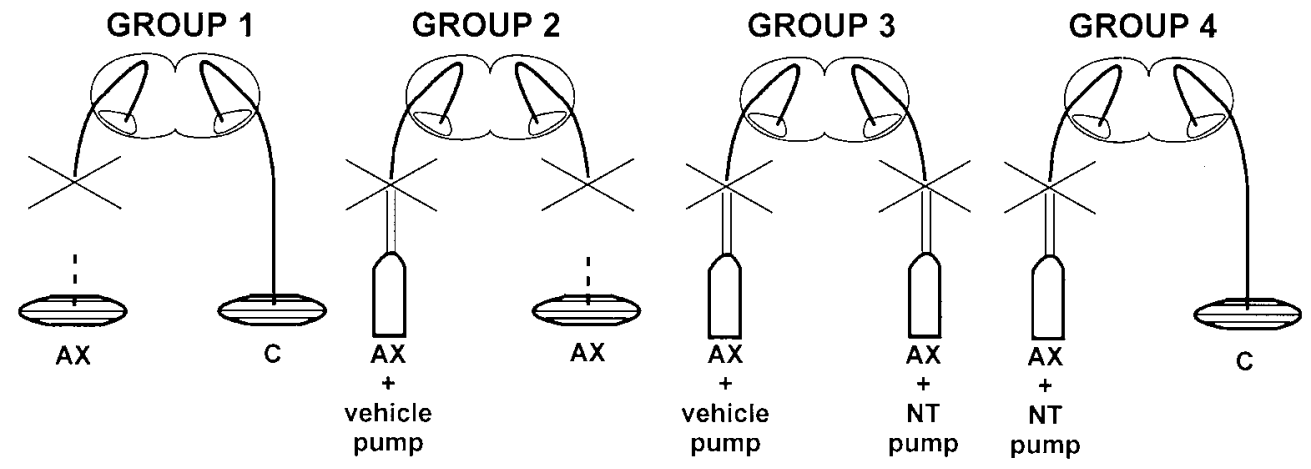
paradigm allowed assessment of neurotrophin effects. Group 4 received a single facial nerve axotomy, followed by implantation of a neurotrophin pump $(A X+N T$ pump $)$ to compare AChE expression after neurotrophin treatment with that in nonaxotomized contralateral $(C)$ FMNs.

demonstrated that exogenous NT-4/5 and BDNF can prevent the decrease in ChAT immunoreactivity after axotomy of adult motoneurons (Chiu et al., 1994; Yan et al., 1994; Friedman et al., 1995; Tuszynski et al., 1996). Based on the these effects, neurotrophins are candidate muscle-derived factors regulating $\mathrm{AChE}$ expression in vivo. Neurotrophin application in vitro induces an increase in total $\mathrm{AChE}$ enzymatic activity in various populations of embryonic neurons (Greene and Rukenstein, 1981; Martinez et al., 1987; Raynaud et al., 1988; Alderson et al., 1990; Ojika et al., 1994), including embryonic motoneurons (Wong et al., 1993). Furthermore, a recent in vivo study reported that BDNF can maintain the survival of avulsed motoneurons, which normally undergo cell death, and that these rescued motoneurons express ChAT and AChE (Kishino et al., 1997).

Neurotrophins have been shown previously to stimulate survival (for review, see Sendtner et al., 1996) and electrophysiological (Munson et al., 1997) responses from motoneurons. In the present study, we assessed the possibility that AChE gene expression in motoneurons may be regulated by the neurotrophin family members found in muscle, i.e., NT-3, NT-4/5, and BDNF. We investigated whether the axotomy-induced reduction in motoneuron AChE enzymatic activity occurs at the mRNA or protein activity level, tested the abilities of the individual neurotrophins to prevent the axotomy-induced changes in AChE mRNA, biochemical activity, and histochemical localization, and examined the expression of trkB and trkC neurotrophin receptors in intact, axotomized, and neurotrophin-treated motoneurons.

\section{MATERIALS AND METHODS}

Experimental paradigms. Adult male Sprague Dawley rats (250-400 gm) were obtained from Charles River Laboratories (Quebec, Canada) and housed in a $12 \mathrm{hr}$ light/dark cycle, with access to a standard diet and water ad libitum. The rats were divided into the following treatment groups, as shown schematically in Figure 1. In group 1, rats received a facial nerve resection involving removal of a $5 \mathrm{~mm}$ nerve segment to prevent reconnection to the distal stump, allowing us to determine the effects of axotomy on motoneuron gene expression. Gene expression in the axotomized facial motoneurons (FMNs) was compared with the contralateral uninjured FMNs. In group 2, one facial nerve was axotomized as for group 1 . The contralateral facial nerve was likewise axotomized, and an osmotic pump containing vehicle was implanted onto the proximal nerve stump. This allowed us to measure any effect of vehicle compared with axotomy alone. In group 3, one facial nerve was axotomized, and and an osmotic pump containing vehicle solution was implanted onto the proximal nerve stump. The contralateral facial nerve was also axotomized and received an osmotic pump containing one of the neurotrophin solutions. This permitted measurement of neurotrophin effects relative to contralateral vehicle treatment. In group 4, one facial nerve was axotomized and received a neurotrophin pump. The contralat- eral facial nerve was left unoperated. This allowed comparison of gene expression in neurotrophin-treated axotomized FMNs to contralateral uninjured motoneurons. Thus, in groups 2 and 3 both facial nerves were axotomized, which the animals tolerated without weight loss. In addition, to avoid bias toward one particular side (left vs right), the left or the right side was randomly selected for neurotrophin treatment in different animals.

The experimental arrangements described for groups 1, 2, 3, and 4 involve comparisons between the left and right facial nuclei within individual animals. This intra-animal comparison was selected to preclude interanimal variabilities in gene expression, as well as to ensure that the populations of neurons compared undergo identical tissue fixation and hybridization conditions. Although it is possible that levels of AChE expression in motoneurons contralateral to axotomy may not be identical to those in motoneurons of completely uninjured rats, the magnitude of our findings are likely to err, if at all, on the slightly conservative side. This is because (1) our results are normalized against the contralateral nucleus so that any contralateral effects of axotomyneurotrophin treatment resulting from release of diff usible factors would tend to reduce rather than increase the statistical significance of neurotrophin effects, and (2) both facial nerves were axotomized in groups 2 and 3 so that contralateral effects are internally controlled.

Animal surgery and pump implantation. All surgery was done according to the guidelines of the Canadian Council for Animal Care and approved by the local Animal Care Committee. The rats were anesthetized with a mixture of sodium pentobarbitol $(32 \mathrm{mg} / \mathrm{kg})$ and chloral hydrate $(150$ $\mathrm{mg} / \mathrm{kg}$ ), and the facial nerve was exposed at its exit from the stylomastoid foramen. The buccal branch of the facial nerve was transected $\sim 4-5 \mathrm{~mm}$ distal to the foramen, taking care not to injure the smaller auricular branch. In neurotrophin-treated rats, an osmotic minipump containing any one of the four neurotrophins (NGF, BDNF, NT-3, or NT-4/5) or vehicle was connected to a SILASTIC tubing (0.025 inches inner diameter $\times 0.047$ inches outer diameter; Dow Corning), which was placed over the nerve stump and held in place with a 6.0 Prolene suture (Ethicon). SILASTIC silicone-like medical adhesive (Dow Corning) prevented leakage from the tubing. Penicillin-streptomycin solution (750 $\mu \mathrm{l}$ at $5000 \mathrm{U} / \mathrm{ml}$ ) was instilled into the wound area, and the skin was closed with wound clips.

Minipump preparation and neurotrophin solutions. Total volume required to fill each minipump $(1 \mu \mathrm{l} / \mathrm{hr}$ flow rate; model 2001; Alzet $)$ and $6-8 \mathrm{~cm}$ of SILASTIC tubing was $\sim 250 \mu \mathrm{l}$. Vehicle solution consisted of $0.8 \%$ saline in $20 \mathrm{~mm}$ sodium phosphate buffer, $\mathrm{pH} 7.2$, containing $0.5 \%$ rat serum albumin as a protein carrier and $100 \mathrm{U} / \mathrm{ml}$ each penicillin and streptomycin antibiotics. The neurotrophins (kindly provided by Regeneron Pharmaceuticals Inc.) were supplied as concentrates in acetate buffer and were then diluted in the vehicle solution to a final concentration of 5,50 , or $500 \mathrm{ng} / \mu \mathrm{l}$. The BDNF concentration range chosen was based on a previous study by Friedman et al. (1995). All pumps were

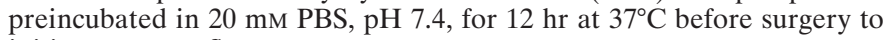
initiate an even flow rate.

Animals were killed by lethal injection of chloral hydrate $(1 \mathrm{gm} / \mathrm{kg}) 7 \mathrm{~d}$ after surgery and perfused transcardially with PBS, followed by $4 \%$ freshly hydrolyzed phosphate buffered paraformaldehyde. The brainstems were post-fixed in $4 \%$ paraformaldehyde for $18 \mathrm{hr}$, cryoprotected with 16 and $22 \%$ sucrose dissolved in $1 \times$ PBS, and quick-frozen in dry 
ice-cooled isopentane. Postmortem analysis confirmed that the free end of the SILASTIC tubings had been maintained over the proximal nerve stump.

In situ hybridization. Each facial nucleus was cut in $12 \mu \mathrm{m}$ sections on a cryostat. Sections were collected on Superfrost Plus slides (Fisher Scientific, Pittsburgh, PA), with each slide containing a section from group 1 together with a section from groups 2,3 , or 4 . The oligonucleotide probe for AChE was complementary to nucleotides 1360-1409 (5'-CAAGTCAATGTGGAGGCACGGTGTTCAAAGATGTAGGCATAGACCCGAGC-3'; GenBank accession number S50879). The trkC probe corresponded to nucleotides 2109-2272 (excluding 2134-2250) (5'-GGAGCATGGTGTGTCCTCCCACCCTGTAGTAATCAGTACTGTAGACG-3'; GenBank accession number L14447), thereby bridging the potential insertion site in the tyrosine kinase domain (Valenzuela et al., 1993). Probes were $3^{\prime}$ end-labeled by incubating $80 \mathrm{ng}$ of the oligonucleotide with terminal transferase $(24 \mathrm{U}),{ }^{35} \mathrm{~S}$-dATP $(125 \mu \mathrm{Ci})$, diethyl pyrocarbonate-treated water $(6 \mu \mathrm{l})$, and $5 \times$ reaction buffer $(5 \mu \mathrm{l})$. The in situ hybridization (ISH) procedure and autoradiography was as described by Verge et al. (1992).

Quantification of ISH and data analysis. As described previously (Kobayashi et al., 1997), a computerized image analysis system (Northern Exposure; Empix Imaging Inc., Mississauga, Ontario, Canada) was used to quantify the ISH signals. Sections were stained in $0.01 \%$ ethidium bromide for $1 \mathrm{hr}$ and rinsed under running demineralized $\mathrm{H}_{2} \mathrm{O}$ for $1 \mathrm{hr}$. Sections from different treatment groups were randomly arranged on the microscope slides, which were then number coded to eliminate any bias during quantification (single blind analysis). Cells were visualized and traced under fluorescence illumination, and the area fraction occupied by grains (i.e., grain density) was then automatically measured from the corresponding dark-field image. Background autoradiographic signal from the white matter running through the facial nucleus was subtracted to obtain a corrected grain density. Axotomy and neurotrophin treatments induce significant increases in motoneuron size, which could dilute the mRNA density and obscure changes in levels of mRNA transcripts within a given neuron. Therefore, the mean ISH signal per neuron was obtained by multiplying the corrected grain density by the approximate cell volume, which was calculated from the cross-sectional area. The quantification was limited to those cells cut through the nucleus/nucleolus, resulting in data collection from $\sim 25-30$ cells per tissue section. For each section, the average ISH signal per neuron per section was expressed as percentage of the signal from the contralateral vehicle-treated motoneurons. At least three sections, $>100 \mu \mathrm{m}$ apart, were quantified per facial nucleus, and the mean percentage was calculated for each animal.

Measurement of AChE enzyme activity. Facial nuclei were punched from fresh frozen brainstems using a blunted cannula. Each nucleus was homogenized on ice $(2 \times 15 \mathrm{sec})$ in $1 \mathrm{ml}$ of a high salt-detergent buffer containing protease inhibitors $(1.0 \mathrm{mg} / \mathrm{ml}$ bacitracin, $25 \mathrm{U} / \mathrm{ml}$ aprotinin $)$. Homogenates were then centrifuged at $20,000 \times g$ for $20 \mathrm{~min}$ at $4^{\circ} \mathrm{C}$, and the supernatants were used immediately for reaction with acetylthiocholine as substrate for AChE (Ellman et al., 1961). Spectrophotometric measurement of AChE activity was performed in the presence of $10^{-5} \mathrm{M}$ tetraisopropylpyrophosphoramide, a nonspecific cholinesterase inhibitor (Gisiger and Stephens, 1988; Jasmin and Gisiger, 1990). Nonspecific hydrolysis was determined by incubating the samples in the presence of 5-bis(4-allyldimethylammonium phenyl)pentanone dibromide (BW284c51), a specific acetylcholinesterase inhibitor. AChE activity per sample was normalized according to the amount of protein measured using a BCA protein assay reagent kit (Pierce, Rockford, IL). In each case, results were normalized against the acetylcholinesterase activity measured within the contralateral intact facial nucleus.

AChE histochemical staining. Coronal sections $(12 \mu \mathrm{m})$ through the facial nucleus of perfused brainstems were mounted onto Superfrost Plus slides (Fisher Scientific) and stored at $-80^{\circ} \mathrm{C}$. Sections were stained using the histochemical technique of Karnovsky and Roots (1964). Specificity of the staining procedure was confirmed by including BW284c51 in the reaction mixture, which eliminated all staining (data not shown).

Reverse transcription-PCR for full-length trkC isoforms. Total RNA was isolated and reverse transcribed into cDNA as described by Kobayashi et al. (1996), with the following modifications. Full length trkC mRNAs were selectively amplified by PCR using previously described primers (Offenhauser et al., 1995) that bracket the potential insertion site within the trkC kinase domain. The amplified cDNA sequences corresponded to both noninserted and inserted full-length trkC mRNA species. Hence, the PCR products had sizes of 299, 341, 374, and 416 bp, corresponding
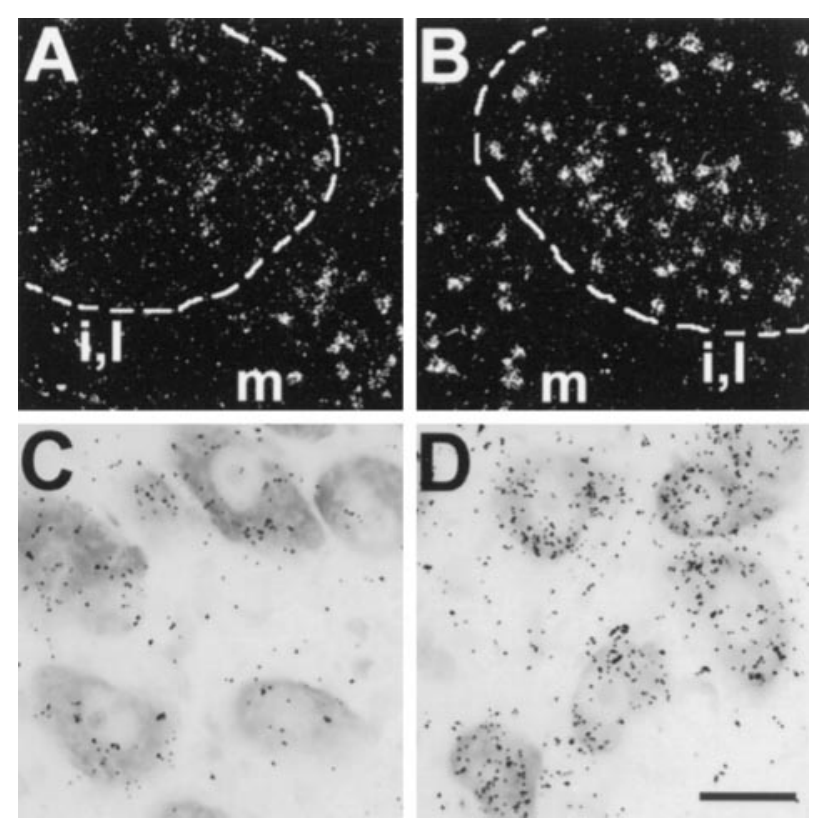

Figure 2. Reduced autoradiographic ISH signal for AChE mRNA in the axotomized facial nucleus. Seven days after resection of the buccal branch of the facial nerves of rats from group 1, dark-field micrographs reveal that ISH signals are reduced within the intermediate and lateral subgroups $(i, l)$ of the axotomized facial nucleus $(A)$ in comparison to the contralateral uninjured facial nucleus $(B)$. Note that the ISH signal is not reduced in the medial subgroup $(m)$, which projects via the nonaxotomized auricular branch of the facial nerve. Higher-magnification bright-field micrographs localize the specific ISH signals to the cresyl violet-stained axotomized $(C)$ and contralateral (D) FMNs. Scale bar (in $D), 30 \mu \mathrm{m}$.

to the noninserted isoform, and 14, 25, and 39 amino acid inserted trkC isoforms, respectively. PCR amplification of trkC species was initially performed between 18 and 32 cycles $\left(45 \mathrm{sec}\right.$ at $94^{\circ} \mathrm{C}, 1 \mathrm{~min}$ at $55^{\circ} \mathrm{C}, 1 \mathrm{~min}$ $30 \mathrm{sec}$ at $72^{\circ} \mathrm{C}$ ) and found to be within the linear range of amplification at 30 cycles. Serial dilutions from 12 to $0.75 \mathrm{ng}$ of total RNA were amplified in $50 \mu \mathrm{l}$ PCR reactions. Amplification of cyclophilin mRNA was used to ensure equivalent amounts of input cDNA (Mearow et al., 1993). PCR products were visualized on $5 \%$ acrylamide gels.

Statistics. For each animal, data from the experimental facial nucleus was normalized against (i.e., expressed as a percentage of) the contralateral side. Within each treatment group, the normalized data from each animal was averaged and expressed as the mean \pm SEM. To test for significant differences between treatment groups, we used a one-way ANOVA, followed by a multiple comparison of the group means with the Student-Newman-Keuls test.

\section{RESULTS}

\section{Effect of axotomy on AChE mRNA expression}

Using rats from group 1 (see Materials and Methods, Experimental paradigms) (Fig. 1), in situ hybridization for AChE mRNA, followed by autoradiography, was used to determine whether the decreased AChE activity found in axotomized motoneurons (Tetzlaff and Kreutzberg, 1984) was caused by downregulation of mRNA levels. Dark-field micrographs, which show the autoradiographic silver grains, clearly demonstrated reduced hybridization signal over the axotomized facial nucleus (Fig. 2A) when compared with the uninjured contralateral facial nucleus (Fig. $2 B$ ). In bright-field micrographs (Fig. $2 C, D$ ), the autoradiographic signal is localized to the facial motoneurons. Quantification of the ISH signal per cell determined that AChE mRNA expression by axotomized FMNs was reduced to $37 \pm$ $4 \% \operatorname{SEM}(n=13$ animals) compared with the noninjured contralateral side. 

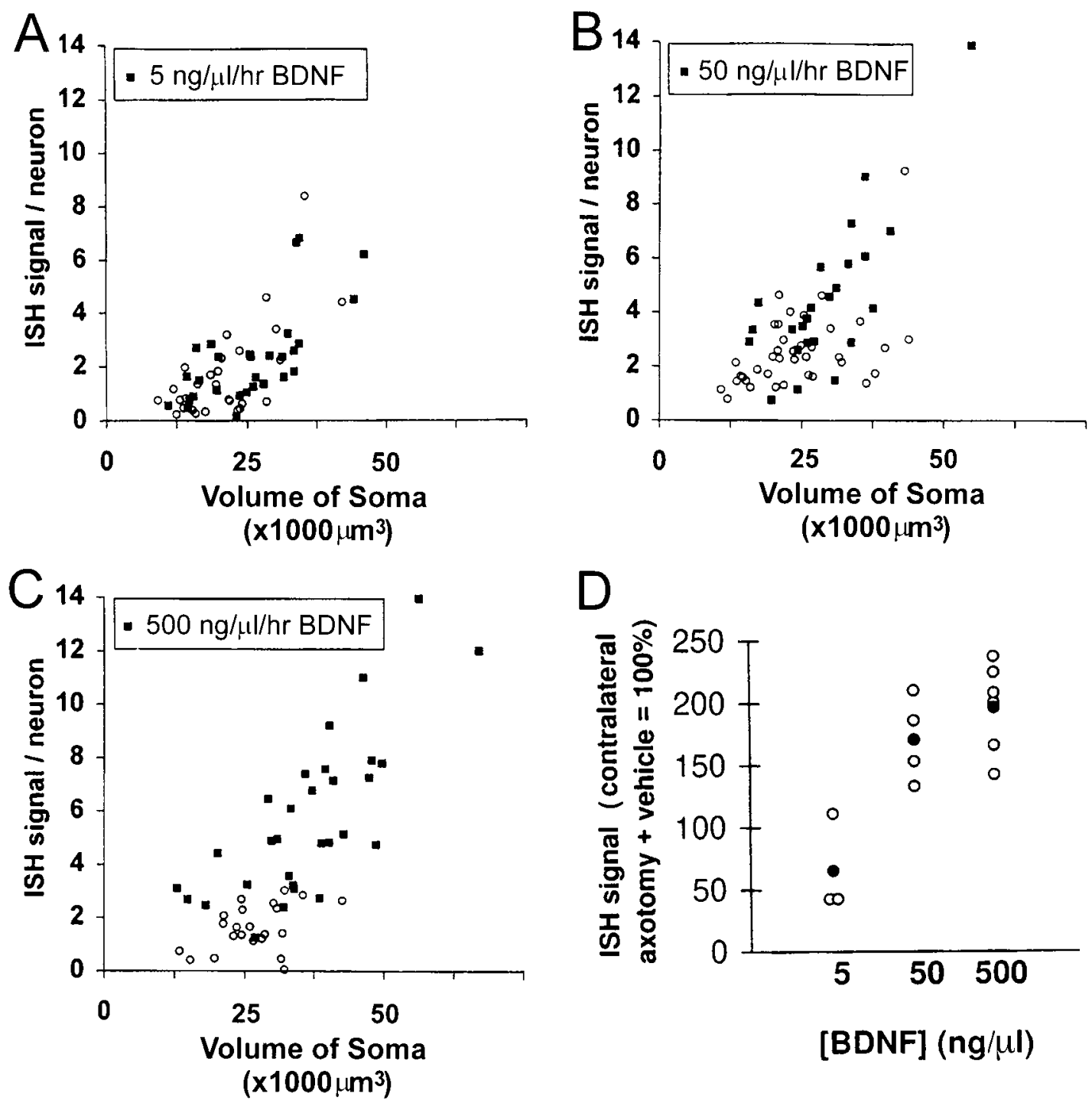

Figure 3. Dose-response analysis of axotomized FMNs to BDNF. Representative scatterplots showing AChE ISH signal per neuron in the facial nuclei of rats from group 3 receiving neurotrophin pumps for $7 \mathrm{~d}$ applications of either $5(A), 50(B)$, or $500 \mathrm{ng} / \mu \mathrm{l} / \mathrm{hr}$ BDNF $(C)$. Open circles represent the contralateral cells, which were axotomized and treated with vehicle. Filled squares represent the axotomized BDNF-treated FMNs. Sections were processed on the same slide for equal ISH conditions. Summary of dose-response data $(D)$ demonstrates similar effects of 50 and $500 \mathrm{ng} / \mu \mathrm{lBDNF}$ treatments on AChE mRNA levels compared with contralateral axotomized FMNs treated with vehicle (normalized to 100\%). D, Open circles represent the mean ISH signal per neuron per animal; filled circles represent the mean of each treatment group.

\section{Dose-response analysis of axotomized FMNs to BDNF}

To identify the concentrations at which axotomized FMNs would respond to neurotrophins in the osmotic pump infusion paradigm, we performed a dose-response analysis using 10-fold increments in BDNF concentration. Rats were treated as shown for group 3 (Fig. 1). Treatment with $5 \mathrm{ng} / \mu \mathrm{l}$ BDNF did not alter AChE mRNA levels in relation to contralateral vehicle inf usion, as measured with in situ hybridization (Fig. 3A). However, infusion of either 50 (Fig. 3B) or $500 \mathrm{ng} / \mu \mathrm{l} \mathrm{BDNF}$ (Fig. 3C) increased AChE mRNA hybridization signal $(171 \pm 17 \%$ SEM; $n=4$ animals; $196 \pm 15 \%$ SEM; $n=6$ animals, respectively). We also measured significantly larger soma sizes with BDNF treatment; importantly, however, the increases in AChE mRNA levels with 50 and $500 \mathrm{ng} / \mu \mathrm{l} \mathrm{BDNF}$ treatments was several-fold greater than the $10-15 \%$ increase in soma volume (data not shown), indicating that the specific signal/cell volume ratio was increased. Further- more, the stimulation of AChE mRNA levels does not represent a pleiotrophic effect on all motoneuron mRNAs, because we found that sections from the same animals did not exhibit a BDNF effect on the expression of c-jun mRNA (data not shown). Dose-response data are summarized in Figure $3 D$, illustrating the similar effects of 50 and $500 \mathrm{ng} / \mu \mathrm{l}$ BDNF treatments on AChE hybridization signal.

\section{Responsiveness of AChE mRNA expression to members of the neurotrophin family}

Because NT-3 and NGF treatments elicited no detectable effects at $50 \mathrm{ng} / \mu \mathrm{l}$, we used the highest neurotrophin dose $(500 \mathrm{ng} / \mu \mathrm{l} / \mathrm{hr})$ to avoid false negative findings. High doses of neurotrophins did not elicit morphological or gene expression changes indicative of high dose toxicity (data not shown).

In animals operated as shown for group 3, low levels of AChE 

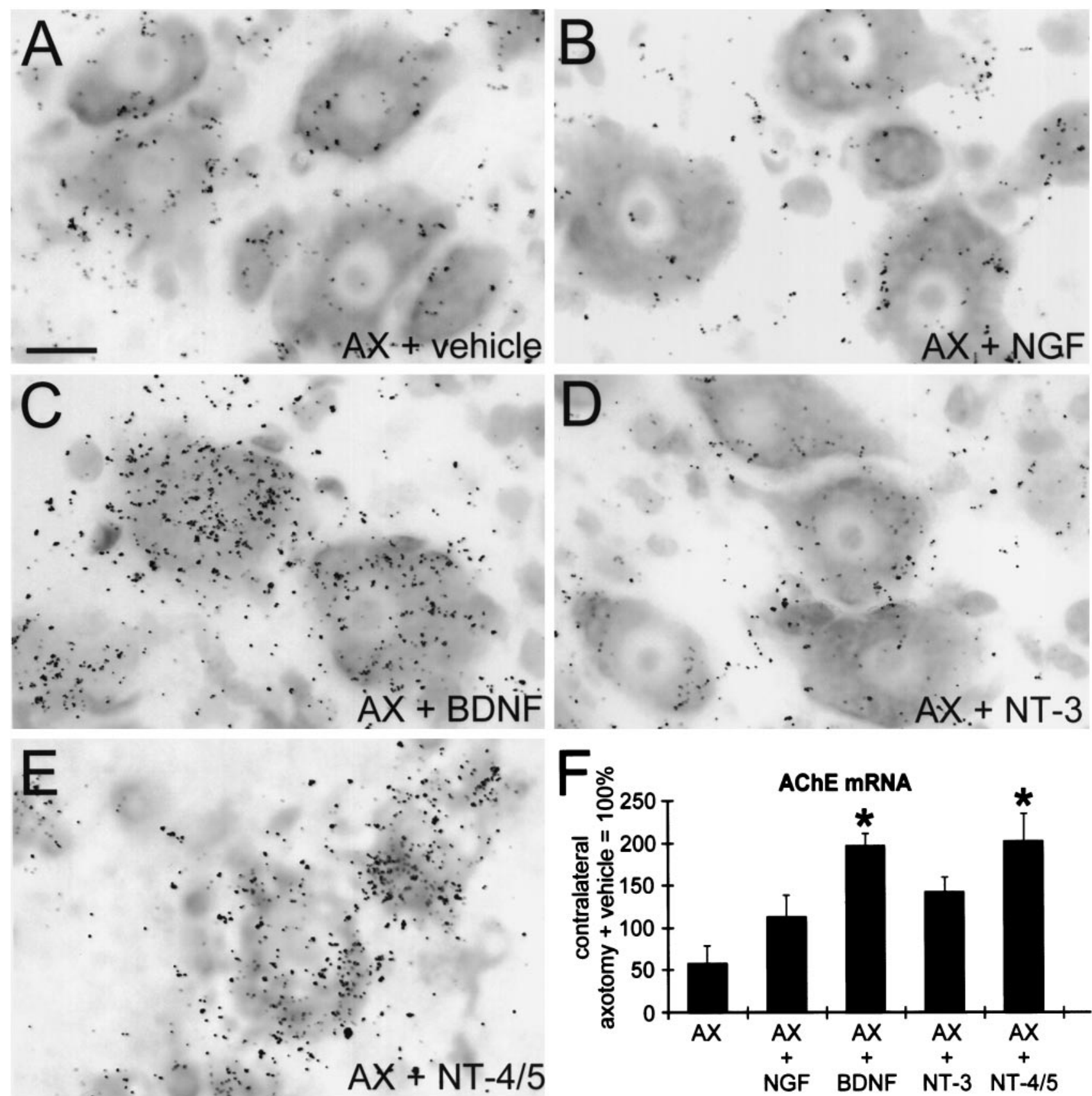

Figure 4. Effects of neurotrophins on FMN ISH signal for AChE mRNA. Cresyl violet-stained sections from rats operated according to group 3. Shown are axotomized FMNs treated with vehicle $(A)$ or $500 \mathrm{ng} / \mu \mathrm{l}$ of NGF $(B)$, BDNF $(C)$, NT-3 $(D)$, or NT-4/5 $(E)$. Note that BDNF- and NT-4/5-treated FMNs maintained AChE mRNA expression, whereas NT-3 and NGF were without obvious effect. Quantification of average ISH signal per neuron, normalized against contralateral vehicle-treated FMNs, confirms statistically significant effects $(* p<0.05)$ of BDNF $(n=6)$ and NT-4/5 $(n=4)$ but not NT-3 $(n=4)$ or NGF $(n=4)(F)$. NT-3 had a marginal effect on AChE mRNA levels; however, this effect did not reach statistical significance. Scale bar (in $A$ ), $20 \mu \mathrm{m}$.

ISH signal were observed over vehicle-treated axotomized FMNs contralateral to neurotrophin-treated FMNs, confirming consistent hybridization conditions and the absence of contralateral effects of neurotrophins (Fig. 4A). FMNs treated with NGF (Fig. $4 B$ ) or NT-3 (Fig. 4D) were not significantly different from their contralateral vehicle-treated controls. However, FMNs treated with BDNF or NT-4/5 exhibited high levels of cytoplasmic ISH signal (Fig. 4C,E, respectively). Interestingly, although treatment with NT-3 was ineffective on the FMN population as a whole, a few FMNs appeared to express higher levels of AChE mRNA (data not shown).

Quantification of the ISH signals using computerized image analysis measurements (Fig. $4 F$ ) determined that treatment of axotomized FMNs with BDNF or NT-4/5 maintained the average ISH signal per neuron at $196 \pm 15(n=6$ animals $)$ and $202 \pm$ $34 \%$ SEM ( $n=4$ animals) respectively, or approximately twofold higher than vehicle-treated contralateral FMNs. ISH signal in response to NGF treatment $(113 \pm 26 \%$ SEM; $n=4$ animals $)$ was 
not significantly different from vehicle control treatment, whereas NT-3 treatment had an average ISH signal per neuron that was $141 \pm 18 \% \operatorname{SEM}(n=4$ animals $)$ of contralateral. However, only BDNF and NT-4/5 treatments yielded statistically higher ISH signals than contralateral vehicle treatment $(p<0.05)$.

A few animals from group 4 were also used for in situ hybridization. In comparison to the contralateral nonaxotomized FMNs, AChE mRNA levels in FMNs from group 4 rats were reduced to $38 \pm 11 \%(\mathrm{SEM})$ with $\mathrm{NGF}(n=2)$ and $27 \pm 3 \%$ (SEM) with NT-3 $(n=2)$ (data not shown). This was not significantly different from axotomy alone $(37 \pm 4 \% ; n=13)$ (Fig. 1). Axotomized motoneurons treated with BDNF, however, actually exhibited higher mRNA levels than the intact contralateral motoneurons $(147 \pm 10 \% ; n=2)$. Taking into account the $\sim 15 \%$ hypertrophy, the specific signal/cell volume ratio was still $\sim 30 \%$ higher in BDNF-treated FMNs than in intact motoneurons, indicating that BDNF actually restores AChE mRNA levels to supranormal levels.

\section{Histochemical localization and biochemical measurement of AChE activity}

To assess whether the BDNF- and NT-4/5-induced maintenance of AChE mRNA expression correlated with higher levels of AChE enzyme activity, sections through the facial nucleus from groups 1, 2, and 3 were processed for AChE histochemistry. Histochemical localization of AChE enzyme activity identified strong reactivity in FMN cell bodies contralateral to an axotomy (Fig. $5 A$ ), which was severely depleted in untreated (Fig. $5 B$ ) and vehicle-treated (Fig. $5 C$ ) axotomized FMNs. Some heterogeneity was noted in the response to NT-3 (Fig. 5D), because many NT-3-treated FMNs displayed moderate AChE activity. More significantly, after treatment with BDNF or NT-4/5, virtually all axotomized FMNs exhibited AChE staining within their cytoplasm (Fig. 5E, $F$, respectively).

To quantitatively measure the amount of AChE activity after treatment, facial nuclei were microdissected from the brainstems of axotomized group 1 and neurotrophin-treated group 4 rats, and the AChE biochemical activity was measured (Fig. 5G). In normal unoperated animals, there was no significant difference in total AChE activity between left and right facial nuclei (102 \pm $9 \%$ SEM; $n=5$ animals), confirming a reproducible microdissection technique of the facial nucleus that was not biased to one side. At $7 \mathrm{~d}$ after axotomy, AChE activity was reduced to $66 \pm$ $9 \%$ SEM ( $n=5$ animals) of the contralateral uninjured facial nucleus, in agreement with previous results (Tetzlaff and Kreutzberg, 1984). Treatment with $500 \mathrm{ng} / \mu \mathrm{l}$ of NT-3 had no significant effect ( $62 \pm 7 \% \mathrm{SEM} ; n=5$ animals) on the expression of total AChE activity, but treatment with $500 \mathrm{ng} / \mu \mathrm{l} \mathrm{BDNF}$ (92 \pm $5 \%$ SEM; $n=4$ animals) and NT-4/5 (95 \pm 7\% SEM; $n=2$ animals) prevented the axotomy-induced decrease in AChE activity. AChE-positive nerve terminals in the immediate vicinity of the FMN cell bodies were evident in all cases.

\section{Effects of axotomy and neurotrophins on trkB and trkC receptor expression}

Because it was unclear how axotomy and neurotrophin treatments might have altered the responsiveness of FMNs to neurotrophins, we examined the expression of trkB and trkC receptors. Axotomy was found to induce opposing changes in expression of full-length trkB and trkC receptors. Consistent with previous reports, we detected an approximately twofold to threefold increase in full- length trkB mRNA within axotomized FMNs (Piehl et al., 1994; Kobayashi et al., 1996), which was not altered by infusion of BDNF or NT-4/5 in our paradigm (data not shown).

In contrast, we identified an axotomy-induced downregulation of trkC mRNA (Fig. 6A,B). Because multiple isoforms of the trkC receptors exist, we used an ISH probe that spans the potential insertion site within the kinase domain and is therefore specific for the full-length noninserted trkC isoform (trkCni). The expression of trkCni was reduced in the axotomized FMNs $7 \mathrm{~d}$ after axotomy, and the downregulation appeared uniform, as illustrated by scatterplot analysis of ISH signals (Fig. 6C). To determine whether this downregulation was directly caused by the loss of target-derived NT-3 ligand, we used the probe specific for trkCni for in situ hybridization to sections from the NT-3treated rats. The decline in trkC hybridization signal was not prevented by NT-3 infusions at concentrations of 500 (Fig. 6D) and $50 \mathrm{ng} / \mu \mathrm{l}$ (data not shown).

The trkC receptor profile within the facial nucleus was further characterized using total RNA extracted from microdissected unoperated and axotomized facial nuclei. Reverse-transcription (RT), followed by PCR using primers bracketing the potential insertion site in the trkC kinase domain, demonstrated the presence of the trkCni mRNA, as well as of inserted full-length trkC isoforms (Fig. 6E). Multiple comparisons of serial dilutions containing 12,6 , and $3 \mathrm{ng}$ of template indicated an approximate twofold to threefold reduction in mRNA for trkCni mRNA, as well as for the larger inserted trkC isoforms. Inserted trkC isoforms appeared to include the 14, 25, and 39 amino acid insert variants, the presumed 14 amino acid variant yielding the strongest band after PCR amplification. Bands for trkCni and the 14 amino acid inserted trkC variant appeared equally intense.

\section{DISCUSSION}

In the present study, we have shown that axotomy of FMNs results in a reduction in their mRNA expression, as well as their total enzyme activity, for the neurotransmitter hydrolyzing enzyme acetylcholinesterase. Although FMNs express both trkB and trkC neurotrophin receptors, only the trkB ligands BDNF and NT-4/5 prevented the decrease in AChE mRNA expression, biochemical enzyme activity, and somal histochemical staining, and stimulated hypertrophy of the FMN cell bodies when infused onto the proximal nerve stump. In contrast, NT-3 and NGF did not have significant effects. The effects of BDNF and NT-4/5 on FMN gene expression and soma size were consistent with the axotomy-induced upregulation of the full-length trkB receptor. In the case of NT-3, the trkC receptor profile was found to consist of comparable levels of the noninserted and inserted isoforms of the full-length receptor, particularly the 14 amino acid variant, and expression of both the noninserted and inserted isoforms was sharply reduced after axotomy, correlating with the lack of NT-3 effects. Injury-induced changes in the neurotrophin receptor mRNA expression was not detectably altered by infusion of the respective ligands.

\section{Regulation of acetylcholinesterase by neurotrophins}

Our results confirm and extend our earlier report that axotomy of adult rat facial motoneurons reduces AChE activity to $\sim 60 \%$ of levels in the uninjured contralateral motoneurons (Tetzlaff and Kreutzberg, 1984). We detected a concomitant decline in AChE mRNA to levels of $30-40 \%$ of contralateral. The more pronounced reduction in mRNA levels than enzyme activity is likely 

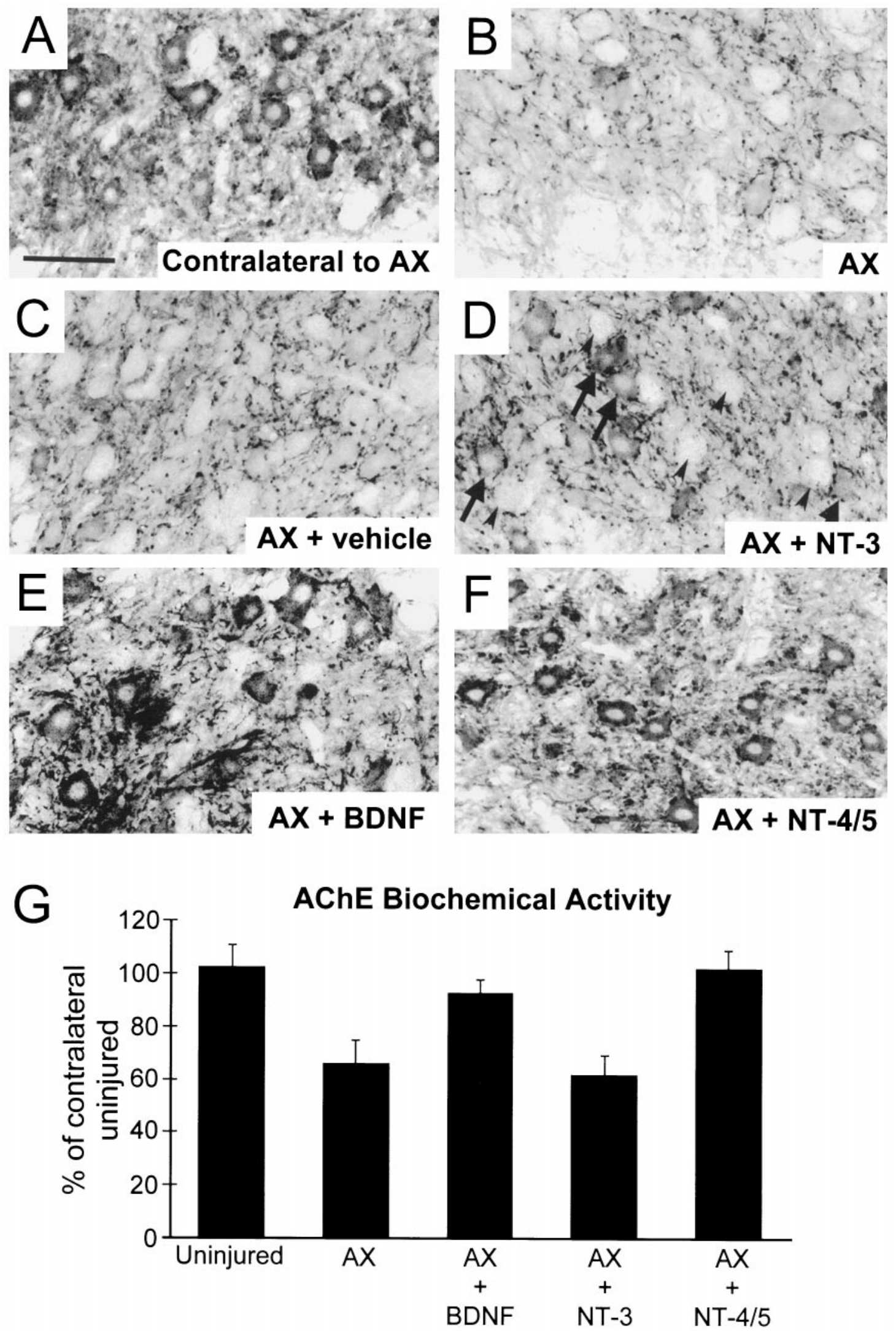

Figure 5. Histochemical and biochemical analyses of AChE enzyme activity in the facial nucleus. Rats were operated as shown for groups 1,2 , and 3 . In group 1 rats, abundant histochemical reaction product clearly identified the cell bodies of the nonaxotomized FMNs contralateral to axotomy ( $A$ ), whereas the axotomized FMNs were depleted of AChE activity $(B)$. In group 2 rats, axotomized FMNs $(B)$ that received vehicle pump implantation were also depleted of AChE activity $(C)$. However, in group 3 rats, virtually all FMNs that received a BDNF $(E)$ or (Figure legend continues) 
explained by a slower turnover of protein than mRNA or by the presence of AChE activity in cholinergic afferent terminals (Li et al., 1995) that were visible on the FMN cell bodies by enzyme histochemistry. However, we cannot exclude the possibility of posttranslational modifications that increase enzyme specific activity.

Treatment of the axotomized FMNs with the trkB ligands BDNF or NT-4/5 maintained AChE mRNA expression and prevented the axotomy-induced reduction of AChE activity. The mechanism underlying the neurotrophin-induced maintenance of AChE mRNA levels has not been established. In vitro studies have demonstrated that the RNA synthesis inhibitors can abolish the NGF-induced stimulation of AChE expression in PC12 cells (Greene and Rukenstein, 1981); however, this may indicate either a direct effect of NGF on AChE transcription or an indirect effect via expression of stabilizing RNA-binding proteins. A recent study in PC12 cells demonstrated that NGF can activate the transcription factor Sp1 (Yan and Ziff, 1997), whose recognition site appears essential for transcriptional activation of the AChE promoter (Getman et al., 1995). On the other hand, stabilization of existing AChE mRNA transcripts was recently shown to underlie the increased AChE mRNA expression that occurs when P19 embryonic carcinoma cells undergo neuronal differentiation (Coleman and Taylor, 1996). Further studies are necessary to differentiate between these possibilities in axotomized motoneurons.

\section{Comparison of neurotrophin effects on AChE and ChAT in motoneurons}

Studies examining neurotrophin effects on ChAT expression in adult motoneurons have used a variety of application paradigms, including local treatment at the lesion site (Chiu et al., 1994; Yan et al., 1994; Friedman et al., 1995; Wang et al., 1997), subcutaneous injections (Yan et al., 1994; Friedman et al., 1995), intravenous injection (Yan et al., 1994), and intracerebroventricular infusion (Yan et al., 1994; Tuszynski et al., 1996). With some exceptions (Clatterbuck et al., 1994; Piehl et al., 1995; Wang et al., 1997), which may be attributable to variations in experimental protocols, the majority of these results have demonstrated that pharmacological doses of BDNF or NT-4/5 maintain ChAT expression in axotomized adult motoneurons. A recent quantitative RNase protection study demonstrated that BDNF maintained ChAT mRNA levels in axotomized hypoglossal motoneurons (Wang et al., 1997); thus, the neurotrophin effects on ChAT expression are likely to be mediated by increases in mRNA transcription or stability rather than rate of translation or specific activity of the enzyme. These results parallel the present findings that BDNF and NT-4/5 maintain AChE mRNA expression and enzyme activity. Collectively, the evidence indicates that signaling in response to either of the trkB ligands BDNF or NT-4/5 can regulate both of the enzymes associated with the cholinergic phenotype at the level of their mRNA expression in facial motoneurons.

In comparison to BDNF and NT-4/5, NT-3 treatment only stimulated a small increase in AChE mRNA, which did not reach statistical significance. NT-3-treated axotomized FMNs were heterogeneously stained by $\mathrm{AChE}$ histochemistry and, unlike axotomy alone or axotomy plus vehicle treatment, included a small number of clearly AChE-positive motoneurons. The reason for the heterogeneous NT-3 effect is unclear. NT-3 has been reported to be the most abundant muscle-derived neurotrophin in adult muscle, with mRNA levels of approximately two to three times those of NT-4/5 and 20 times those of BDNF (Funakoshi et al., 1995; Griesbeck et al., 1995). Furthermore, potent effects of NT-3 on motoneurons during embryonic and neonatal stages of development have been described (Wong et al., 1993; for review, see Sendtner et al., 1996). However, there are few reported effects of NT-3 on mature motoneurons (Haase et al., 1997), and to our knowledge, regulation of motoneuron transmitter enzymes in adult rats by NT-3 has not been reported. The limited NT-3 effect that we detected was not attributable to the quality of NT-3, because the same batch was effective in parallel investigations on other neurons within the CNS (Giehl et al., 1995; Giehl and Tetzlaff, 1996). One possibility for the minor NT-3 effects is that only sensory afferents and $\gamma$-motoneurons might be exposed to muscle-derived NT-3, because the main source of NT-3 in mature muscle appears to be intrafusal muscle spindles (Copray and Brouwer, 1994); since the facial motonucleus is known to contain only $\alpha$-motoneurons, it is possible that they are not normally responsive to NT-3. However, mature $\alpha$-motoneurons have been shown to express trkC receptors (Merlio et al., 1992; Henderson et al., 1993; Johnson et al., 1996) and are capable of retrogradely transporting iodinated NT-3 (Di Stefano et al., 1992). We therefore investigated whether the partial NT-3 effects on axotomized motoneurons may be attributable to the composition of, or injuryinduced changes in, the trkC receptor profile.

\section{Axotomy differentially regulates trkB and trkC receptor expression}

Axotomy of FMNs has been shown to lead to an upregulation of mRNA for the full-length trkB isoform (Piehl et al., 1994; Kobayashi et al., 1996), which is consistent with the responsiveness of axotomized motoneurons to treatment with BDNF or NT-4/5. We found that this twofold to threefold mRNA upregulation was not detectably altered by the infusion of either BDNF or NT-4/5 onto the nerve stump (data not shown). In other studies, BDNF infusion into the midbrain of adult rats also did not alter trkB mRNA levels and resulted in a prolonged analgesia (Frank et al., 1997); thus, it is possible that findings of reduced trkB immunoreactivity after BDNF treatments (Dittrich et al., 1996; Frank et al., 1996, 1997) may be attributable to increased receptor turnover

\section{$\longleftarrow$}

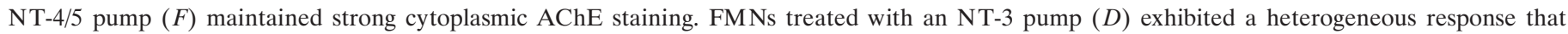

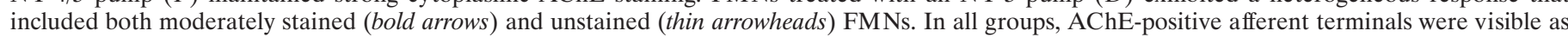

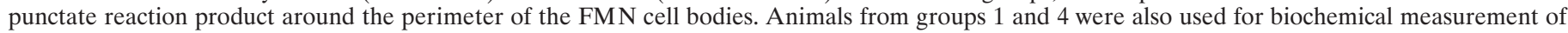

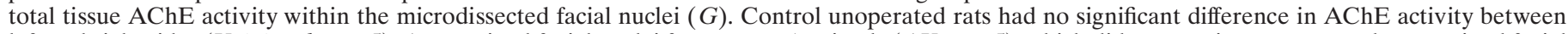

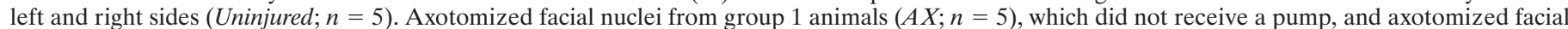

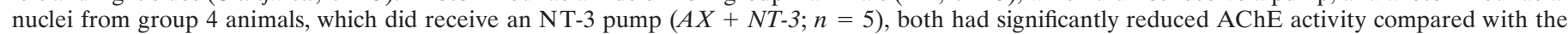

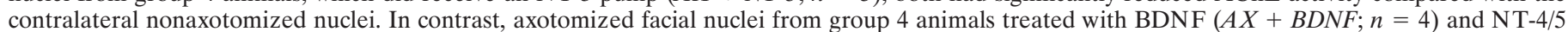

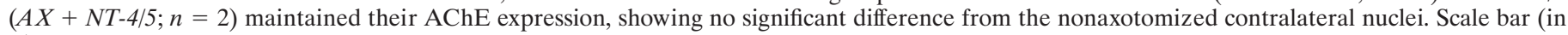
A), $80 \mu \mathrm{m}$. 

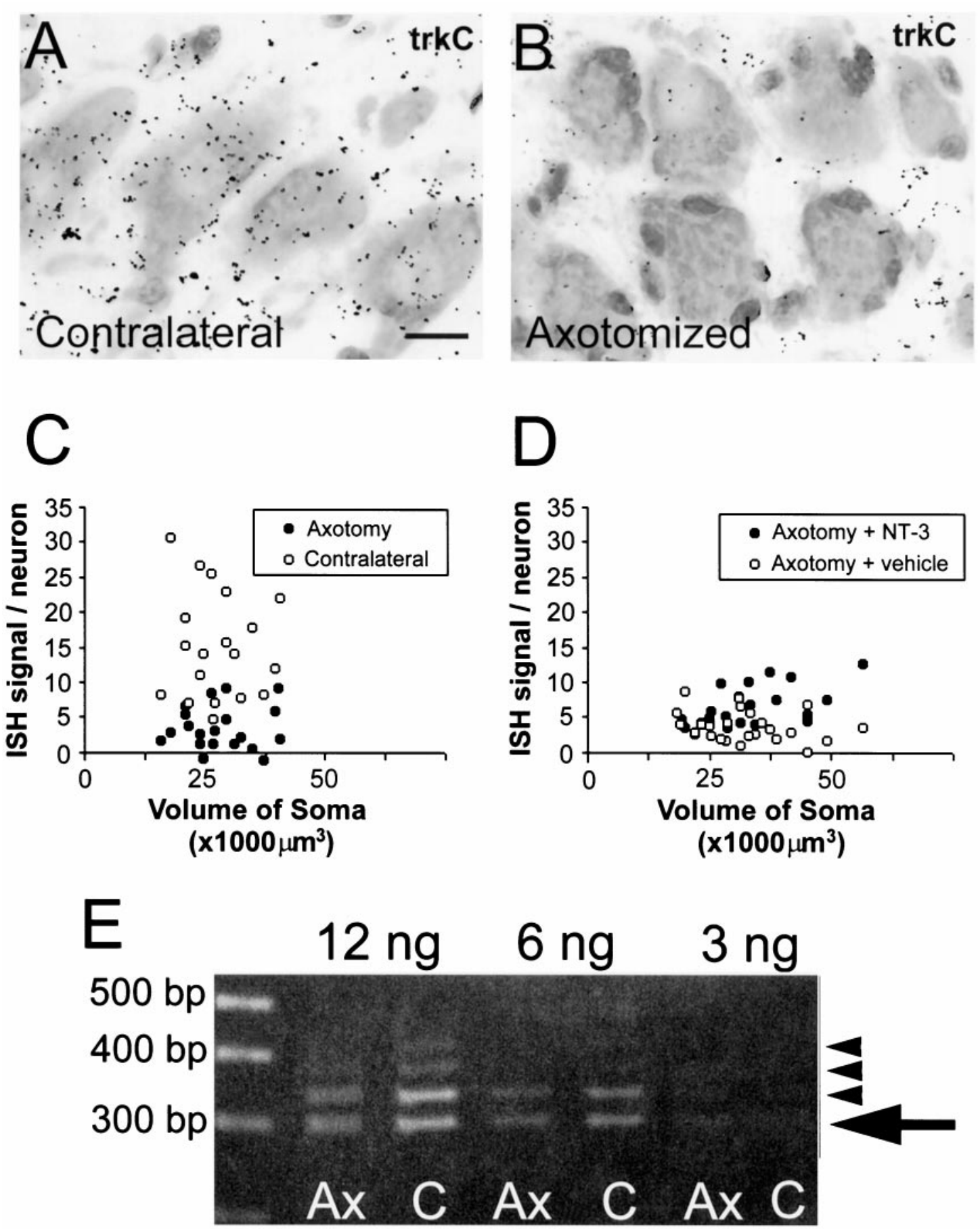

Figure 6. Analysis of the trkC receptor profile in axotomized and neurotrophin-treated FMNs. Autoradiographic ISH signal for noninserted full-length trkC receptor mRNA in nonaxotomized contralateral $(A)$ and axotomized $(B)$ FMNs. Representative scatterplots illustrate the axotomy-induced downregulation of noninserted full-length trkC mRNA $(C)$, which is not significantly changed by $7 \mathrm{~d}$ inf usion of NT-3 ligand onto the proximal nerve stump $(D)$. Representative serial dilutions of RT-PCR products generated using primers that bracket the kinase insertion site $(E)$. Noninserted $(l a r g e$ arrow) and inserted (small arrowheads) isoforms of full-length trkC mRNAs are detected in the facial nucleus $7 \mathrm{~d}$ after axotomy. Note the axotomy-induced twofold to threefold reduction in levels of the noninserted, as well as the inserted, trkC mRNAs. The apparent band sizes are consistent with the full-length trkC isoform sizes of $299 \mathrm{bp}$ (noninserted), as well as 341, 374, and $416 \mathrm{bp}$, representing the 14, 25, and 39 amino acid insertion variants, respectively. Scale bar (in $A$ ), $20 \mu \mathrm{m}$.

rather than downregulation of trkB expression (Frank et al., 1997).

In contrast to the upregulation of the full-length trkB receptor, we found mRNA for the noninserted full-length trkC receptor to be downregulated after axotomy, offering one explanation for the limited NT-3 effects on AChE expression. Inf usion of NT-3 did not prevent this trkC downregulation. To further characterize the trkC expression, we tested for the presence of inserted isoforms 
of full-length trkC receptors, which carry insertions of 14, 25, or 39 amino acids within their kinase domain (Tsoulfas et al., 1993; Valenzuela et al., 1993). The presence of such inserts within the trkC kinase domain appears to limit its signaling capabilities (Tsoulfas et al., 1996; Gunn-Moore et al., 1997) by interfering with the sustained activation of the mitogen-activated protein kinase pathway (Gunn-Moore et al., 1997). In vitro studies have shown that PC12 cells respond to NT-3 with neurite outgrowth when transfected with the noninserted full-length trkC but not when transfected with inserted full-length trkC variants (Lamballe et al., 1993; Tsoulfas et al., 1993; Valenzuela et al., 1993). The use of RT-PCR primers that bracket the potential kinase insertion site allowed us to identify the presence of both noninserted and inserted trkC receptor isoforms within the microdissected facial nucleus, as well as demonstrate that both inserted and noninserted full-length trkC isoforms are downregulated after axotomy.

Because we used RNA extracted from the microdissected facial nucleus, we cannot exclude a non-neuronal contribution to the expression of inserted trkC isoforms. However, we believe them to be predominantly of neuronal origin, because (1) virtually all ISH signals were located over neurons when using the extracellular domain probe common to all trkC isotypes (data not shown), and (2) the inserted trkC isoforms were downregulated in a manner similar to the noninserted trkC isoform. Because NT-3 binding to trkC is followed by receptor dimerization and mutual phosphorylation, the presence of inserted isoforms may exert a dominant negative effect on noninserted trkC signaling pathways, contributing to the mitigated responsiveness of axotomized motoneurons to NT-3. Further studies will be required to determine whether a differential distribution of inserted and/or truncated trkC receptors accounts for the heterogeneous effects of NT-3.

\section{Conclusions}

The roles of endogenous muscle-derived neurotrophins for mature motoneurons have not been clearly established. NT-4/5 is expressed in an activity-dependent manner in skeletal muscle, and NT-4/5 injection into muscle elicits motoneuron sprouting (Funakoshi et al., 1995). Recently, inhibition of endogenous trkB ligands in muscle has been shown to reduce motoneuron conduction velocity, further suggesting a dynamic regulation of motoneuron properties by endogenous neurotrophins (Munson et al., 1997). The present findings showing the potent effects of NT-4/5 and BDNF on AChE mRNA and total enzyme activity, together with their reported effects on ChAT expression, support the concept of a broad influence of trkB ligands on the cholinergic phenotype of mature motoneurons. We also demonstrated that the most abundantly expressed neurotrophin in muscle, NT-3, appears to have only limited effects on neurotransmitter enzyme expression in adult motoneurons after axotomy and that this may be attributable to the presence of inserted trkC receptor isoforms that can limit the responsiveness to NT-3. Furthermore, axotomized motoneurons downregulate their trkC expression, which most likely renders them less responsive to NT-3 after injury.

\section{REFERENCES}

Alderson RF, Alterman AL, Barde Y-A, Lindsay RM (1990) Brainderived neurotrophic factor increases survival and differentiated functions of rat septal cholinergic neurons in culture. Neuron 5:297-306.

Appleyard ME (1992) Secreted acetylcholinesterase: non-classical aspects of a classical enzyme. Trends Neurosci 15:485-490.
Bernard V, Legay C, Massoulie J, Bloch B (1995) Anatomical analysis of the neurons expressing the acetylcholinesterase gene in the rat brain, with special reference to the striatum. Neuroscience 64:995-1005.

Chiu AY, Chen EW, Loera S (1994) Distinct neurotrophic responses of axotomized motor neurons to BDNF and CNTF in adult rats. NeuroReport 5:693-696.

Clatterbuck RE, Price DL, Koliatsos VE (1994) Further characterization of the effects of brain-derived neurotrophic factor and ciliary neurotrophic factor on axotomized neonatal and adult mammalian motor neurons. J Comp Neurol 342:45-56.

Coleman BA, Taylor P (1996) Regulation of acetylcholinesterase expression during neuronal differentiation. J Biol Chem 271:4410-4416.

Copray JCVM, Brouwer N (1994) Selective expression of neurotrophin-3 messenger RNA in muscle spindles of the rat. Neuroscience 63:1125-1135.

Davies AM (1994) The role of neurotrophins in the developing nervous system. J Neurobiol 25:1334-1348.

Di Stefano PS, Friedman B, Radziejewski C, Alexander C, Boland P, Schick CM, Lindsay RM, Wiegand SJ (1992) The neurotrophins BDNF, NT-3, and NGF display distinct patterns of retrograde axonal transport in peripheral and central neurons. Neuron 8:983-993.

Dittrich F, Ochs G, Grosse-Wilde A, Berweiler U, Yan Q, Miller JA, Toyka KV, Sendtner M (1996) Pharmacokinetics of intrathecally applied BDNF and effects on spinal motoneurons. Exp Neurol 141:225-239.

Dupree JL, Bigbee JW (1994) Retardation of neuritic outgrowth and cytoskeletal changes accompany acetylcholinesterase inhibitor treatment in cultured rat dorsal root ganglion neurons. J Neurosci Res 39:567-575.

Dupree JL, Bigbee JW (1996) Acetylcholinesterase inhibitor treatment delays recovery from axotomy in cultured dorsal root ganglion neurons. J Neurocytol 25:439-454.

Ellman GL, Courtney KD, Andres V, Featherstone RM (1961) A new and rapid colorimetric determination of acetylcholinesterase activity. Biochem Pharmacol 7:88-95.

Frank L, Ventimiglia R, Anderson K, Lindsay RM, Rudge JS (1996) BDNF down-regulates neurotrophin responsiveness, trkB protein and trkB mRNA levels in cultured rat hippocampal neurons. Eur J Neurosci 8:1220-1230.

Frank L, Wiegand SJ, Siuciak RM, Lindsay RM, Rudge JS (1997) Effects of BDNF infusion on the regulation of TrkB protein and message in adult rat brain. Exp Neurol 145:62-70.

Friedman B, Kleinfeld D, Ip NY, Verge VM, Moulton R, Boland P, Zlotchenko E, Lindsay RM, Liu L (1995) BDNF and NT-4/5 exert neurotrophic influences on injured adult spinal motor neurons. J Neurosci 15:1044-1056.

Funakoshi H, Frisen J, Barbany G, Timmusk T, Zachrisson O, Verge VMK, Persson H (1993) Differential expression of mRNAs for neurotrophins and their receptors after axotomy of sciatic nerve. J Cell Biol 123:455-465.

Funakoshi H, Belluardo N, Arenas E, Yamamoto Y, Casabona A, Persson H, Ibanez CF (1995) Muscle-derived neurotrophin-4 as an activity-dependent trophic signal for adult motor neurons. Science 268:1495-1499.

Getman DK, Mutero A, Inoue K, Taylor P (1995) Transcription factor repression and activation of the human acetylcholinesterase gene. J Biol Chem 270:23511-23519.

Giehl KM, Mestres P, Tetzlaff W (1995) BDNF and NT-3 exert differential and overlapping effects on GAP-43 and T $\alpha 1$-tubulin expression in axotomized corticospinal neurons of the rat. Soc Neurosci Abstr 21:1056.

Giehl KM, Tetzlaff W (1996) BDNF and NT-3, but not NGF, prevent axotomy-induced death of rat corticospinal neurons in vivo. Eur J Neurosci 8:1167-1175.

Gisiger V, Stephens HR (1988) Localization of the pool of G4 acetylcholinesterase characterizing fast muscles and its alteration in murine muscular dystrophy. J Neurosci Res 19:62-78.

Greene LA, Rukenstein A (1981) Regulation of acetylcholinesterase activity by nerve growth factor. Role of transcription and dissociation from effects on proliferation and neurite outgrowth. J Biol Chem 256:6363-6367.

Greenfield SA (1984) A noncholinergic action of acetylcholinesterase (AChE) in the brain: from neuronal secretion to the generation of movement. Cell Mol Neurobiol 11:55-77. 
Greensmith L, Vrbova G (1996) Motoneurone survival: a functional approach. Trends Neurosci 19:450-455.

Griesbeck O, Parsadanian AS, Sendtner M, Thoenen H (1995) Expression of neurotrophins in skeletal muscle: quantitative comparison and significance for motoneuron survival and maintenance of function. J Neurosci Res 42:21-33.

Gunn-Moore FJ, Williams AG, Tavare JM (1997) Analysis of mitogenactivated protein kinase activation by naturally occurring splice variants of TrkC, the receptor for neurotrophin-3. Biochem J 322:193-198.

Haase G, Kennel P, Pettmann B, Vigne E, Akli S, Revah F, Schmalbruch H, Kahn A (1997) Gene therapy of murine motor neuron disease using adenoviral vectors for neurotrophic factors. Nat Med 3:429-436.

Hagg T, Fass-Holmes B, Vahlsing HL, Manthorpe M, Conner JM, Varon $\mathrm{S}$ (1989) Nerve growth factor (NGF) reverses axotomy-induced decreases in choline acetyltransferase, NGF receptor and size of medial septum cholinergic neurons. Brain Res 505:29-38.

Hammond P, Rao R, Koenigsberger C, Brimijoin S (1994) Regional variation in expression of acetylcholinesterase mRNA in adult rat brain analyzed by in situ hybridization. Proc Natl Acad Sci USA 91:10933-10937.

Henderson CE, Camu W, Clement M, Gouin A, Poulsen K, Karihaloo M, Rullomas M, Evans T, McMahon SB, Armanini M, Berkemeier L, Phillips H, Rosenthal A (1993) Neurotrophins promote motor neuron survival and are present in embryonic limb bud. Nature 363:266-270.

Jasmin BJ, Gisiger V (1990) Regulation by exercise of the pool of G4 acetylcholinesterase characterizing fast muscles: opposite effect of running training in antagonist muscles. J Neurosci 10:1444-1454.

Johnson H, Hokfelt T, Ulfhake B (1996) Decreased expression of TrkB and TrkC mRNAs in spinal motoneurons of aged rats. Eur J Neurosci 8:494-499.

Karnovsky MJ, Roots L (1964) A “direct coloring" thiocholine method for cholinesterase. J Histochem Cytochem 12:219-221.

Kishino A, Ishige Y, Tatsuno T, Nakayama C, Noguchi H (1997) BDNF prevents and reverses adult rat motor neuron degeneration and induces axonal outgrowth. Exp Neurol 144:273-286.

Kobayashi NR, Bedard AM, Hincke MT, Tetzlaff W (1996) Increased expression of BDNF and trkB mRNA in rat facial motoneurons after axotomy. Eur J Neurosci 8:1018-1029.

Kobayashi NR, Fan D-P, Giehl KM, Bedard AM, Wiegand SJ, Tetlaff W (1997) BDNF and NT-4/5 prevent atrophy of rat rubrospinal neurons after cervical axotomy, stimulate GAP-43 and T $\alpha 1$-Tubulin mRNA expression, and promote axonal regeneration. J Neurosci 17:9583-9595.

Koliatsos VE, Clatterbuck RE, Winslow JW, Cayouette MH, Price DL (1993) Evidence that brain-derived neurotrophic factor is a trophic factor for motor neurons in vivo. Neuron 10:359-367.

Kou SY, Chiu AY, Patterson PH (1995) Differential regulation of motor neuron survival and choline acetyltransferase expression following axotomy. J Neurobiol 27:561-572.

Krejci E, Duval N, Chatonnet A, Vincens P, Massoulie J (1991) Cholinesterase-like domains in enzymes and structural proteins: functional and evolutionary relationships and identification of a catalytically essential aspartic acid. Proc Natl Acad Sci USA 88:6647-6651.

Lamballe F, Klein R, Barbacid M (1991) trkC, a new member of the trk family of tyrosine protein kinases, is a receptor for neurotrophin-3. Cell 66:967-979.

Lamballe F, Tapley P, Barbacid M (1993) trkC encodes multiple neurotrophin-3 receptors with distinct biological properties and substrate specificities. EMBO J 12:3083-3094.

Lams BE, Isacson O, Sofroniew MV (1988) Loss of transmitterassociated enzyme staining following axotomy does not indicate death of brainstem cholinergic neurons. Brain Res 475:401-406.

Landis SC (1990) Target regulation of neurotransmitter phenotype. Trends Neurosci 13:344-350.

Landwehrmeyer B, Probst A, Palacios JM, Mengod G (1993) Expression of acetylcholinesterase messenger RNA in human brain: an in situ hybridization study. Neuroscience 57:615-634.

Layer PG, Willbold E (1995) Novel functions of cholinesterases in development, physiology and disease. Prog Histochem Cytochem 29:1-94.

Layer PG, Weikert T, Alber R (1993) Cholinesterases regulate neurite growth of chick nerve cells in vitro by means of a non-enzymatic mechanism. Cell Tissue Res 273:219-226.

Legay C, Bon S, Vernier P, Coussen F, Massoulie J (1993) Cloning and expression of a rat acetylcholinesterase subunit: generation of multiple molecular forms and complementarity with a Torpedo collagenic subunit. J Neurochem 60:337-346.

Levey AI, Wainer BH, Mufson EJ, Mesulam M-M (1983) Colocalization of acetylcholinesterase and choline acetyltransferase in the rat cerebrum. Neuroscience 9:9-22.

Li W, Ochalski PA, Brimijoin S, Jordan LM, Nagy JI (1995) C-terminals on motoneurons: electron microscope localization of cholinergic markers in adult rats and antibody-induced depletion in neonates. Neuroscience 65:879-891.

Lowrie MB, Vrbova G (1992) Dependence of postnatal motoneurones on their targets: review and hypothesis. Trends Neurosci 15:81-84.

Martinez HJ, Dreyfus CF, Jonakait GM, Black IB (1987) Nerve growth factor selectively increases cholinergic markers but not neuropeptides in rat basal forebrain in culture. Brain Res 412:295-301.

Massoulie J, Susman J, Bon S, Silman I (1993) Structure and functions of acetylcholinesterase and butyrylcholinesterase. Prog Brain Res 98:139-146.

Mearow KM, Kril Y, Diamond J (1993) Increased NGF mRNA expression in denervated rat skin. NeuroReport 4:351-354.

Merlio J-P, Ernfors P, Jaber M, Persson H (1992) Molecular cloning of rat trkC and distribution of cells expressing messenger RNAs for members of the trk family in the rat central nervous system. Neuroscience 51:513-532.

Munson JB, Shelton DL, McMahon SB (1997) Adult mammalian sensory and motor neurons: roles of endogenous neurotrophins and rescue by exogenous neurotrophins after axotomy. J Neurosci 17:470-476.

Offenhauser N, Bogm-Matthaei R, Tsoulfas P, Parada L, Meyer M (1995) Developmental regulation of full-length trkC in the rat sciatic nerve. Eur J Neurosci 7:917-925.

Ojika K, Mitake S, Kamiya T, Kosuge N, Taiji M (1994) Two different molecules, NGF and free-HCNP, stimulate cholinergic activity in septal nuclei in vitro in a different manner. Brain Res Dev Brain Res 79:1-9.

Peterson GM, Lanford GW, Powell EW (1990) Fate of septohippocampal neurons following fimbria-fornix transection: a time course analysis. Brain Res Bull 25:129-137.

Piehl F, Frisen J, Risling M, Hokfelt T, Cullheim S (1994) Increased trkB mRNA expression by axotomized motoneurons. NeuroReport 5:697-700.

Piehl F, Ji RR, Cullheim S, Hokfelt T, Lindholm D, Hughes RA (1995) Fibroblast growth factors regulate calcitonin gene-related peptide mRNA expression in rat motoneurons after lesion and in culture. Eur J Neurosci 7:1739-1750.

Raynaud B, Faucon-Biguet N, Vidal S, Mallet J, Weber MJ (1988) Regulation of neurotransmitter metabolic enzymes and tyrosine hydroxylase mRNA level by nerve growth factor in cultured sympathetic neurones. Development 102:361-368.

Schotzinger R, Yin X, Landis S (1994) Target determination of neurotransmitter phenotype in sympathetic neurons. $\mathrm{J}$ Neurobiol 25:620-639.

Sendtner M, Holtmann B, Hughes RA (1996) The response of motoneurons to neurotrophins. Neurochem Res 21:831-841.

Srivatsan M, Peretz B (1997) Acetylcholinesterase promotes regeneration of neurites in cultured adult neurons of Aplysia. Neuroscience 77:921-931.

Tetzlaff W, Kreutzberg GW (1984) Enzyme changes in the rat facial nucleus following a conditioning lesion. Exp Neurol 85:547-564.

Thoenen H (1995) Neurotrophins and neuronal plasticity. Science 270:593-598.

Timmusk T, Belluardo N, Metsis M, Persson H (1993) Widespread and developmentally regulated expression of neurotrophin-4 mRNA in rat brain and peripheral tissues. Eur J Neurosci 5:605-613.

Tsoulfas P, Soppet D, Escandon E, Tessarollo L, Mendoza-Ramirez JL, Rosenthal A, Nikolics K, Parada LF (1993) The rat trkC locus encodes multiple neurogenic receptors that exhibit differential response to neurotrophin-3 in PC-12 cells. Neuron 10:975-990.

Tsoulfas P, Stephens RM, Kaplan DR, Parada LF (1996) TrkC isoforms with inserts in the kinase domain show impaired signaling responses. J Biol Chem 271:5691-5697.

Tuszynski MH, Mafong E, Meyer S (1996) Central infusions of brainderived neurotrophic factor and neurotrophin-4/5, but not nerve growth factor and neurotrophin-3, prevent loss of the cholinergic phenotype in injured adult motor neurons. Neuroscience 71:761-771. 
Valenzuela DM, Maisonpierre PC, Glass DJ, Rojas E, Nunez L, Kong Y, Gies DR, Stitt TN, Ip NY, Yancopoulos GD (1993) Alternative forms of rat TrkC with different functional capabilities. Neuron 10:963-974.

Verge VMK, Merlio J-P, Grondin J, Ernfors P, Persson H, Riopelle RJ, Hokfelt T, Richardson PM (1992) Colocalization of NGF binding sites, trk mRNA, and low-affinity NGF receptor mRNA in primary sensory neurons: responses to injury and infusion of NGF. J Neurosci 12:4011-4022.

Wang W, Salvaterra PM, Loera S, Chiu AY (1997) Brain-derived neurotrophic factor spares choline acetyltransferase mRNA following axotomy of motor neurons in vivo. J Neurosci Res 47:134-143.

Webb CP, Nedergaard S, Giles K, Greenfield SA (1996) Involvement of the NMDA receptor in a non-cholinergic action of acetylcholinesterase in guinea-pig substantia nigra pars compacta neurons. Eur J Neurosci 8:837-841.

Wong V, Arriaga R, Ip NY, Lindsay RM (1993) The neurotrophins BDNF, NT-3 and NT-4/5, but not NGF, up-regulate the cholinergic phenotype of developing motor neurons. Eur J Neurosci 5:466-474.

Yan G-Z, Ziff EB (1997) Nerve growth factor induces transcription of the $\mathrm{p} 21$ WAF1/CIP1 and cyclin D1 genes in PC12 cells by activating the Sp1 transcription factor. J Neurosci 17:6122-6132.

Yan Q, Matheson C, Lopez OT, Miller JA (1994) The biological responses of axotomized adult motoneurons to brain-derived neurotrophic factor. J Neurosci 14:5281-5291. 